\section{Beyond Boundaries: Illustration Futures}

Más allá de los límites: futuros de la ilustración

Roderick Mills

"Art = Design $=$ Art...? The boundaries are not so clear now. I would like to make them much less clear."

Gaetano Pesce, 1988

In the advent of globalisation, digital technology, the Internet, and economic forces the need for developing a sustainable illustration practice across multiple platforms has never been as important. This should be seen as a natural extension of what an education in Illustration can facilitate, rather than a retreat into the craft of the past. The blurring of traditional distinct boundaries within Art and Design education means that Illustration is at the centre of many meeting points, and a fulcrum into other areas.

Gradually there is a move away from the sole practitioner, to be replaced by a multi-disciplinary approach, a collaborative practice working upon both self-generated work and commercial commissions. Illustration should be exploring new narrative forms in the digital age, through personal viewpoint/opinion in a journalistic approach rather than perpetuating a possibly outmoded economic system of client and commissioner?

In light of the gradual move in editorial work onto web based platforms it offers many opportunities for moving image content that sits somewhere in-between the still image and animation. Moving image needs to be a part of the vocabulary of a modern illustrator.

The web itself is speeding up the consumption of imagery to such a degree that a career in marketing terms of the average illustrator is shortening. Mario Hugo, of Hugo \& Marie Creative Agency recently ascertained that 5 years is the average 'life span' of an illustrator. Therefore within education there has to be an emphasis upon developing a sustainable practice post graduation, with transferable skills to adapt into other areas of the industry such as design, art direction, and collaboration as a means of broadening the ambitions of illustration Faced with a generation of students consuming images at such an indiscriminate rate, (the scanning, grazing of information) how we teach the value of an image, to contextualise content from the web becomes increasingly relevant within education.

In 2007 book 'Teaching Illustration' by Steven Heller and Marshall Arisman, Heller stated

Palabras clave: Límites borrados, ilustración híbrida, Gifs, Animación, Film: ilustración dentro de una línea temporal, Auto-autor Investigación de ilustración Key words: Blurred Boundaries, Hybrid Illustration, Gifs, Animation, Film: Illustration within a timeline Self-Authorship, Illustration Research
En la colección de ensayos en Design Without Boundaries (Diseño sin limites): comunicación visual en transición, 1988." Rick Poydisciplinas conforme la autoría dentro del Diseño Gráfico llegó a ser normal. Con el advenimiento de la tecnología digital y la revolución de la información las prácticas de trabajo han avanzado hacia la práctica hibrida y un enfoque multidisciplinar - el diseñador como autor, el diseñador como emprendedor. En un tiempo en el que la imagen es ubicua y el consumo de imágenes vía internet ha acelerado, la popularidad, o conciencia de que la ilustración ha mezclado en nuestra cultura visual cotidiana, perm tiendo accesibilidad para lustración, mientras hace más difícil destacarse sobre el ruido de Internet. Este trabajo pretende explorar los acontecimientos recientheren列 la definicion, cuestionando que significa hoy ser un ilustrador, $y$ que puede significar mañana. Ya no es prerrequisito para los graduados en ilustración establecerse como freelance, unico miembro del equipo, sino que requiere un enfoque más abierto, en un tiempo en el que las carreras profesionales no son lineales y no es necesario un aprendizaje de toda la vida para evolucionar en la practica creativa de cada uno.
"Illustration can no longer afford to be parochial. The days are over when the beautiful crafted picture was the quintessential virtue. Illustrators have branched out into animated film, graphic novels, Web and exhibition displays, to name a few options."

A combination of economic factors and the technological/information revolution has required the illustrator to diversify and to communicate on multiple platforms. As once it was about print media and the reproduction of a picture, an image, the requirements for illustrators today may include animation, moving image, gallery, environment and 
installation, interactivity, mobile apps... to augment the traditional areas of editorial, publishing, advertising, design, and self-initiated.

Within education those studying illustration come from varied backgrounds, and the popularity of visual communication courses, or those as options in fine art faculties reflect how the discipline has become omnipresent in visual culture.

Since the publishing of Pen and Mouse: Commercial Art and Digital IIlustration by Roanne Bell \& Angus Hyland in 2001, arguably one of the first books about illustration rather than an annual or listings resource book, the proliferation of such books catapulted illustration as a field of practice or study. This public awareness of illustration would seem to have accelerated with the foundation of blogs such as It's Nice That, the online publishing platform founded in 2007, which headed the phenomenon of 'blogging' culture.

With the proliferation of illustration work seen online, it can perhaps be argued that visual literacy has improved, for the encyclopedic nature of the online has exposed all sorts of visual practitioners to a world wide audience. This has also necessitated the development of skills to be able to properly contextualize work, both in terms of its design, or curatorial decisions, to editorial needs and how one writes about the work, going further than publishing vacuous images. Essentially to offer authority and meaning to the work, in order to slow the reader down rather than passing rapidly by.

Mirroring the developments in contemporary art, the future illustrator needs to be conversant in various media to express themselves, and also a greater understanding of the context of work within a wider visual culture, in an ever-connected world.

Ronald Jones, artist, critic and educator, commenting during the same discussion in Frieze magazine exploring 'Super-Hybridity' talks about the concept of a T-shaped artist:

"You will want people involved who I would describe as T-shaped: very deep in one discipline but promiscuous enough to have the grace and confidence to move across disciplines in search of the hybrid or super-hybrid."

For illustration some of this is naturally driven by economic forces, such as in editorial work the move towards online editions of newspapers and magazines, making it essential that illustrators can translate their image to one in a timeline, and the possibilities of durational work, leading to the popularity of GIFs, the Graphic Interchange Format that works through Photoshop to enable simple animations. For the so called YouTube, or Laptop TV generation, moving image is part and parcel of how we navigate the world, from tablets and mobile devices, to animated billboards, so it would seem natural that image-makers such as illustrators use technology for storytelling.

Marshall Arisman, Chair of the MFA Illustration as Visual Essay Department at the School of Visual Arts in New York has said that all students should be learning technology for developing new authorial work - especially animation. Through his programme at SVA has been an advocate of establishing an authorial practice for many years, of the need to finding your own visual identity through subject matter. Not merely of aligning yourself to something akin to a fine art practice, but through a subject matter defining a market for the commercial application of what you do.

This entrepreneurial spirit can be most readily seen in self-publishing, from print publishers such as Nobrow, Le Gun, Nieves, Ditto Press... the thriving Zine and Comic Book scene evidence of the resurgence of analogue print technology like screenprint and risograph, to the internet enabling every illustrator to publish online. You can call yourself an illustrator now and only self-publish, without engaging with the commercial profession. Whether this is a positional stance, or just the avoidance of the skill to answer a brief, I'm not sure, but it does once again signify the diversity of practice within illustration.

This sense of authorship, self-publishing, Walter Benjamin's idea of 'Artist as Producer' is nothing new in illustration, especially in the UK where there has been a long tradition of artist/illustrator such as William Blake or Thomas Bewick, working to both commissions and generating their own content. The only difference these days is the accessibility of the means of production, and the advent of 'desktop' publishing that has brought such capability closer to the designer or illustrator. In 'The Designer as Producer' from 1998, Ellen Lupton, graphic designer and curator of contemporary design at Cooper-Hewitt, National Design Museum in New York City stated that;

"The challenge for educators today is to help designers become the masters, not the slaves, of technology."

In recent times within illustration this spirit of self-publishing has morphed into the idea of produce, away from the narrative, or projects with ideas, to the production of self-promotional items such as t-shirts, tea towels and ceramics - vehicles for the application of illustration rather than an authorial voice. This confusion has also manifested itself in education; with sometimes in the UK degree shows resembling jumble sales, rather than art, or communication design? The tension between research and professional practice exists at a time when the professional world of illustration could be said to be in peril, or more accurately being questioned. Expressing an opinion or a strong subject matter has perhaps never before been as vital?

Indeed part of Lawrence Zeegen's argument in the Creative Review article Where is the content? Where is the comment? 2012 that commented upon the annual 'Pick Me Up: Graphic Art Fair held at Somerset House in London. In the piece Lawrence point out that for illustrators to take the next step from graphic art fairs, they would need to form new partnerships, for illustration collectives to bridge the gap with design practices, to produce more opinionated work, rather than self-referential product feeding the ever-growing student population in illustration. Whilst 
graphic artist such as Javier Mariscal run their own studios and have become a brand, there are few exemplars of illustrators going beyond the sole practitioner. Push Pin Studio and more recent collectives such as Peepshow are examples of how collaboration can further the ambitions of illustration, but there is perhaps a future in an age of inter-disciplinary crossovers that illustrators will collaborate with furniture designers or other such disciplines to go beyond the realm of the $2 \mathrm{D}$ image makers.

Jörg Heiser, in an article entitled 'Analyze This' Frieze Magazine Issue 133 states:

"In art forms, hybridity could mean the blurring of traditional distinct boundaries between artistic media such as painting, sculpture, film, performance, architecture, as natura and physical science, industry, technology, literature, popular culture, as natural and physical science, industry, technology, literature, popular culture, innovation in contemporary art."

It could be argued that it is important for illustration to look beyond the discipline, to have a broader perspective from the historical context of the commercial profession. Indeed it may be necessary to look at other disciplines for the theoretical framework of illustration. In Rosalind Krauss' published paper 'Sculpture in the Expanded Field' for MIT Press she states:

"For, within the situation of postmodernism, practice is not defined in relation to a given medium - sculpture - but rather in relation to the logical operations on set of cultural terms, for which any medium - photography, books, lines on walls, mirrors, or sculpture itself-might be used."

What I would argue though is that this goes beyond the mere use of different media, or the use of technological tools, to illustration being a way of thinking, rather than the application. At times the debate can slip into the area of craft, of the direct technique of making the work, evoking nostalgia and the old notion of a cottage industry rather than aligning itself to Graphic Design.

Now surely the old debate around digital and analogue within illustration is redundant? The recent upsurge of interest for 'folk' could also be said to fit this desire of returning to the hand made, which whilst having a role, can be a refuge away from the digital. Illustration does have an innate insularity, the private in making the work. Essential perhaps in developing a visual language, but can lead to a very inward looking profession, when it should feel confident in its position within the public.

Dan Fern, the former Head of MA Communication Art \& Design at the Royal College of Art, interviewed by Rick Poynor in Eye Magazine 22, Autumn 1996, memorably put it this way:

"A lot of illustration sits very awkwardly alongside the contemporary digital typography scene. It can look naïve, almost folksy".
The former UK based critic Tom Lubbock writing when presenting the Critic's Award for the Association of Illustrators Images 29 annual in 2005 contentiously referred to Illustrations avoidance of influence from contemporary art, but I would suggest that with the digital or the web revolution, and economic events of recent times, the discipline will need to embrace diversity or risk isolating itself in some folk inspired aesthetic. As Tom Lubbock explained;

"I half suspect that illustration has become a haven for visual artists who want to escape from what fine art has become. But whatever its limitations as art, this work is a source of strength that illustration should not neglect'

That there is a change in the very practice of illustration, or that as a discipline it has moved beyond the definition in some way? Perhaps evidenced by the popularity of illustration as a subject to study? In the UK there has been a steady growth of those studying illustration at undergraduate level, at a time when rising student fees would have suggested the opposite. Maybe the fact that illustration is so broad as a subject, omnipresent in visual culture, democratic as an art form helps to make it more accessible to those considering a career in the visual arts?

Alejandro Jodorowsky, the Chilean filmmaker of cult classics such as El Topo (1970) and The Holy Mountain (1973) has referred to the notion that we are in an age where things have lost their definition:

"...We are no longer in the fixed time of the telephone. Now we are in the time of the iPhone. A telephone is no longer just a telephone. With this you can send messages, take photos, take pictures, listen to music... If you use it like a telephone it is a telephone.

This sense of working without labels mirrors the interdisciplinary nature of contemporary art practices, with artists appropriating the language of design to communicate to an ever increasing visually literate public. Jodorowsky was to say:

"...Why do I need a definition? When I can make films I will make films, otherwise I will make comics..."

This switching across media and audience does have resonance for illustration. Marshall Arisman also references this freedom for an illustrator to cross between self-initiated or non-commercial and the commercial;

I see illustration simply as another outlet for the work I do. I think the publishing industry is using me, and I am using the publishing industry. It seems a fair exchange most of the time'

This loosening of definitions would seem to offer illustrators opportunities to cross-disciplines and increasing collaborations, beyond the traditional boundaries of the past. Referring back to Dan Fern's interview in Eye Magazine, he went on to say; 
The traditional relationship between designers and illustrators are changing rapidly. Illustration is going through a very difficult phase for a range of reasons. One is that the traditional role of the illustrator was at the end of a complex chain of events which was completed by the illustrator's phone ringing."

Illustration would seem to be able to circumnavigate the traditional routes of commissioning, if only because of how we access images through the Internet, and being closer to the client without recourse to mediate through an agent. Recently an whole range of technological developments have affected the very discipline of illustration, from the speed of turning around commissions, to the all pervasiveness of social media. Dan Crichlow, Creative Director of Dutch Uncle illustration agency, in a recent discussion mentioned that during the negotiations of a commission for an ad campaign the illustrator's social profile was as important as the work itself. No longer is illustration simply providing the image, but illustration itself has become part of the fabric of visual culture, and the narrative of a campaign?

The advent of blogs such as It's Nice That has greatly popularized the discipline, offering a constant array of talent, accessed daily, and changing how one can be sourced for commissions. Perhaps also negatively speeding the consumption of images via the Internet? There was a time previously when the only access to illustration was the printed outcome of a job, or in one of the many annuals, listing books advertising illustrators. Nowadays accessibility to such work is only a keyboard tap away, with artists sourced from the world over. Mario Hugo, New York based illustrator and co-founder of Hugo and Marie Creative Agency has frankly mentioned that the average professional life span of an illustrator is perhaps 5 to 7 years. Whilst understanding that this refers to a particular area of illustration, where fashion or trend is important, I do think that it has broader ramifications for the industry as whole. If only as students have a constant accessibility to great 'cool' images. Once again Mario Hugo has suggested that this might have improved, or educated illustrators in making better images? In any case a look at any of the various trending blogs displaying a perpetual feed of illustration talent, gloriously backlit on our screens.

Jörg Heiser, the co-editor of Frieze magazine has said;

"With the help of digital technology and the swift circulation of knowledge, time seems to have dramatically and suddenly compressed. Children seem to be growing up faster and have a rapidly changing relationship with (and access to) new technologies. As a side-effect, social and ethnic identities have become mor complicated..."

The existence of work within a temporal world, when references are immediately commoditized as the latest trend or fashion, it is ever more important to understand your own practice as an illustrator. To appreciate where you stand - beyond simply being an image-maker with social and political responsibilities. A much wider perspective of the discipline necessary to raise the critical discourse and to help $\overline{\text { Roderick Mills }}$

He is a practicing Artist, lllustrato Educator, Writer and Curator. Since graduating from the Royal College cross most areas of the llustrapon industry including editoriat, publishing corporate literature, and advertising for various Internation clients including: The BBC, Royal Mall, Penguin Books, Pentagram Design, The Design Museum, Opéra National de Paris, The New York Times, Le Monde, The Nation Theatre, The New Yorker, and is represented by Heart Artists Age of Excellence USA, Society of Publication Design SPOTS. The Folo Society Awards, The Quentin Blake Award for Narrative Illustration, ED\&F Man Portfolio Prize, AOI mages Pentagram Prize, and work is included in the collection of Bibliothéque nationale de France Réserve des livres rares. Roderick is also an International Award winnin inm-maker, Course Leader for the f Brighton - having spoken and de ivered academic papers at various international conferences, co-founder of the Mokita Illustration Forum, egular contributor to Varoom Magazine, and Deputy Chairman of Unssociation of lllustrators in the United Kingdom.

those studying illustration gain critical consumption skills to filter out the constant visual noise. There can be a tendency to simply see the Internet as another marketing platform for illustration, without realizing the profound change this informational revolution is effecting. Even on a more simplistic level for illustrators, it will become much harder to stand out amongst the web mosaic of images - Arguably it will be the subject matter or content that will drive such decisions rather than a matter of aesthetic or trend?

The increased amount of illustration conferences, the gradua need to write the history of the discipline, to help forge a discourse in illustration could be said essential to properly identify what it means to be an illustrator today amidst the diversity offered as creative practices become ever more hybrid in nature? Not only is it a question of mastering techniques or materials, but also what the artist or illustrator chooses to make-work about, whether that is self-initiated work, or self-promotional to effect commercial commissions. Illustration cannot flourish in isolation, and has to look at itself within visual culture of today. The profession is moving away from the template of sole trader or single practitioner, to exist in a wider context within art and design incorporating interactivity, participation, programming, networks, provocations, and storytelling. Not only are the boundaries of the discipline becoming blurred, but also possible models of interchange between the illustrator and commissioner, and how in the future the public might engage with illustration.

\section{Bibliography:}

ARISMAN, M (2007) In: HELLER, S \& ARISMAN, M. Teaching Illustration. Allworth Press, U.S.

BRAZELL, D \& DAVIES, J. (2011) Making Great Illustration. A \& C Black Publishers Lto FERN, D. (1996) In: Poynor, R. (ed). Reputa-

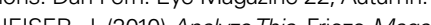
ne, Issue 133, September.

HELLER, S. (2007) In: HELLER, S \& ARISMAN, M. Teaching lllustration. Allworth Press,

JODOROWSKY, A. (2007) In: Alejandro Jodorowsky Interview [Online] Youtube. https./Mmw. Youtube.com/watch?v=WstrV_soyMw [Accessed: 14/4/2015]
BBC Collective, Full article: www.bbc.co.uk/ dna/collective/A22045169

JONES, R. (2010) In: HEISER, J. (ED). Analyze This. Frieze Magazine, Issue 133, September. ded Field. The MIT Press.

UBBOCK, T. (2005) Introduction. In: Images 29The Best of Contemporary Illustration. The Association of lllustrators,

C Graphic Designer. Allworth Press, New York. POYNOR, R. (2002) Design Without Boundaries: Visual Communication in Transition. Booth-Clibborn Editions. 